modern tillage produce as good results, and work in the United States has even indicated that straw left on the land may be detrimental to the subsequent growth of certain leguminous and forage crops. Several speakers expressed the belief that increased co-operation between the farming industry and the straw-pulping industry could make much more straw available for the latter, and so initiate a new and valuable national pulping industry.

The next paper, by H. R. Blanford, dealt with forestry in relation to paper and board, and was an excellent survey which confirmed in detail the general views sot out above. J. Macdonald then dealt with British woodlands and their production, and as such his paper was also of great general interest. However, it led to the inevitable conclusions that in Britain the surplus land is needed too badly to grow food to enable the existing forests to be extended; and that the present forest-wood is either unsuitable for pulping, or else is needed for other more urgent purposes. No indigenous woodpulp industry therefore seems likely in Britain.

The final paper was an authoritative contribution from the Mead Corporation (United States) dealing with the removal of ink from waste paper. Considerable technical progress has been made in this direction; but again, so far as Great Britain is concerned, the matter hinges around the supplies of waste paper available, and this point was dealt with in a supplementary paper by $\mathrm{S}$. F. Smith. Apart from imported waste paper, supplies in Britain of this material must necessarily be limited by the production of good paper, although the collection of waste paper continues to be of the greatest importance as an economy measure. It is interesting to note that the waste paper collected, expressed as a percentage of the total consumption of paper and board, has never been so high as in 1942 , when it was 61 per cent. During 1949-51 it ranged from 28-31 per cent as against 20 per cent in 1939 . Since the figure for 1951 corresponds only to about one million tons, it seems that there is still much room for improvement here. This point, and the danger of fluctuations between shortages and excesses, and means of evening them out, were emphasized by several speakers.

In the summing up which concluded the conference, common ground was shared by most speakers who held the view that, owing to sudden increases in demand (due to factors such as post-war development and rearmament, and accentuated by economic and distribution difficulties), the world in general, and Great Britain in particular, is at present experiencing a serious pulp shortage. The supplies of fibrous material existing in the world (especially of wood) should, however, certainly be sufficient to satisfy the immediate demand could they be made available. It is highly probable, moreover, that as education develops (particularly in Asia) pulp supplies can be stepped up to meet the increasing demand for paper, although temporary shortages may arise, just as trade cycles cause booms and slumps in other commodities. For all this the importance of vegetable fibres other than of wood should not be overlooked or even minimized, though quantitatively their possibilities may be less. Indeed, it seems certain that indigenous short-fibred plants such as straw, bagasse, bamboo, etc., will play a vital part in bridging the gap in various parts of the world, especially if the promise held out by new developments in pulping methods is realized.

Juirus Grant

\section{EAST AND WEST IN SCIENCE}

SYMPOSIUM of the British Society for the History of Science was held on April 17 to discuss "Historical Scientific Contacts between East and West". 'This topic is attracting increasing attention from historians of science; it was an important theme of the Sixth International Congress of the History of Science held at Amsterdam in 1950; it is to be a prominent theme of the next year's conference at Jerusalem.

The present symposium was organized by $\mathrm{Mr}$. F. H. C. Butler and included an important paper by Dr. Joseph Needham on Chinese mechanical sciences. The president of the Society, Dr. F. Sherwood Taylor, took the chair for the afternoon session, which was concerned especially with Arabic science. Chinese influences were discussed in the evening session, when Prof. J. R. Partington, a vice-president, took the chair:

The mysterious numbers such as $1,3,5,8,28$, which so often play an important part in alchemy (as is evident in the recent work of Kraus), were discussed by Dr. H. E. Stapleton in his paper on "Possible Sources of the Numbers on which Jabirian Alchemy is Based". He showed that the numbers could have been derived by magic squares or by the areal measurements of Babylonian ziggurats, and hinted that possibly the magic square was itself in origin a formula concealing temple measurements; such an idea might account for the magical potency with which it was regarded.

A discussion by Dr. A. Armitage and others followed; but no conclusive evidence appeared to be available to settle the various interesting problems raised. Dr. Sherwood Taylor pointed out that Arabic efforts to express all elements in numbers may seem futile to us until we remember that modern physicists are doing very much the same thing.

Dr. D. M. Dunlop (Cambridge) then spoke on "John Mesue and his Work". John Mesue is little known to-day, but was extravagantly praised during the Renaissance when both his genuine work and a mysterious Latin corpus (associated with a mythical Mesue Junior) were ranked very highly. An investigation of the Arabic biographies shows that the real John Mesue (Yuhannā b. Mâsawaih) belonged to the early Baghdad phase of Arabic science in the early ninth century. His father had been employed in a subordinate capacity at Jundī-Sābūr ; although unable to read, the clinical experience received there enabled him, after he had moved (c. 790) to Baghdad, to gain the confidence of the Caliph Harūn ar-Rashid. Mesue's mother, a Slav, had been a slave-girl, but at Baghdad the young son John received a good medical education (under Jibrīl b. Bukhtyashū') and rapidly rose to fame and fortune, living in the suburb Dâr ar-Rum (Abode of the Greeks) and being considered one of the leaders of the Christian community in the city.

Many anecdotes are reported of his majlis (assembly), a combination of lecture-room and consultinghour; but they reveal more of his wit than his methods - although it is evident that examination of urine and feeling the pulse were the standard clinical preliminaries. Freer perhaps from superstition than Galen's work, his "Axioms", written c. 830, emphasize common sense and moderation; he wrote a book (now lost) on the dissection of an ape which had been brought to the court in A.D. 835 by a visiting Abyssinian prince. His pupil, Ḥunain b. Ishāa, from 
Hïrah, learnt Greek and became famous for his translations from the Greek into Syriac and Arabic. $\mathrm{He}$ was later Mesue's friend, and made translations of Galen specifically for him. Mesue, like many of his contemporaries, appreciated rather than understood Greek, for Syriac was at that time the language of science; he was an innovator inasmuch as he himself wrote in Arabic. The editor of 'Ali 'Tabari's "Paradise of Wisdom" in 1928 described that work (c. 850) as "the oldest extant Arabic medical compendium"; the description should more properly be given to Mesue's "Medical Axioms". Certainly Mesue's is the oldest Arabic medical work known to the medieval West; hence he was sometimes called the "Evangelist of Medicine" by the Latins.

In a paper on "The Curve of Cultural Interchange between China and the West", Mr. D. Justin Schove referred to a graph published in the Meteorological Magazine $(78,14 ; 1949)$ and discussed the historical geography of early science in relation to the fluctuations of the trade routes. In the sixth century B.c., diffusion was taking place especially from the West to the East; Babylonian star observations had reached China at least by $c .525$ B.C. (Chatley, Bezold); iron reached China by the same route in the same century and is specifically mentioned by 513 B.c. Shortly afterwards, other ideas such as the ox-drawn plough and coffins as in Egypt were adopted in China in the same way. Horse archers reached China before 300 B.C., and cavalry soon replaced chariotry in warfare all over Eurasia: in China c. 200 B.c. ; in Britain not until the defeat of Boadicea. Pythagorean musical ratios and the statement of the 'theorem' ascribed to him reached China in the late third century B.c. Meanwhile the use of gold and the ideas of alchemy based on Babylonian chemistry had developed in China (as Dubs has shown) about the fourth century B.c.

The known development of the Silk Road took place from 200 B.C. to A.D. 300 , and in the last two centuries Chinese science reached remarkably high developments-the inventions of paper and the seismograph being developed at this time.

About A.D. 300, unrest on the steppes seriously interfered with the Silk Road. China and the West began, especially from A.D. 400, to depend on India as intermediary for their cultural intercourse. The art of glass-making (the Chinese had depended on imports from the West) was introduced to the Chinese by the Indo Scythians in the fifth century, and in the sixth century the silkworm was concealed in a bamboo cane and introduced to the West, probably by Indian monks.

At this time there was a great inflow of Indian ideas to China. Religion and art were even more important than science, but from about 440 there occurred a Chinese scientific revival stimulated by fresh ideas received from India. After 650, science declined in India itself and also in China and the West; but the Chinese invention of paper received in Mesopotamia about 750 helped to stimulate the scientific renaissance which began at Baghdad hortly afterwards. Meanwhile, Chinese ideas of a.lchemy returning via the Silk Road had an important influence on medieval alchemy, which the Arabs began to develop at this time. In the thirteenth century cultural interchange began on a great scale, but the fruits were short-lived. In the eighteenth century Chinese influence on the arts of Europe was very considerable. Leibniz had suggested that Chinese missionaries should be sent to Europe, and
Wolff was expelled from Halle for an address in praise of Confucius; but most of the scientific heritage of China had by then already reached Europe.

In the discussion which followed, Prof. E. G. R. Taylor referred to the evidence of flourishing trade both by land and sea shown in Ptolemy's "Geography" and expressed surprise that scientific interchange had not been even greater. Prof. Partington recalled how twenty years ago it had been imagined that Chinese alchemy was an offshoot of the Arabian. Dr. Stapleton pointed out that the arrival in China of ideas ascribed to Pythagoras was probably an introduction of ideas already developed in the Fertile Crescent where Pythagoras himself had gained his knowledge by travel.

Dr. J. Needham gave a foretaste of his forthcoming volumes on the history of Chinese science in his paper on the "Transmission of Ideas in the Mechanical Sciences between China and Europe". $\mathrm{He}$ showed the high attainments of the Chinese in mechanical engineering as early as the first century A.D., and convinced the audience with illustrations from original sources that the Chinese were superior to Europe or Islam in these fields from about the beginning of the Christian era until A.D. 1400.

Ideas which travelled from China to Europe included: the single-wheel barrow, sailing carriages, the camp-mill (mobile rotary quern), the squarepallet chain-pump (to Europe about 1540), rotary fans, deep drilling, efficient harness- $(a)$ the breast strap (c. fourth century B.C. in China), and $(b)$ the collar (c. A.D. 700 in China)-horizontal waterwheel, metallurgical blowing-engines (by A.D. 31 in China), tilt-hammers and water-driven trip-hammers, edgerunner mills (gunpowder mill), iron-chain suspension bridge, vertical-warp loom, drawloom, flyer in silkwinding, revolving bookcase, kite, and helicopter top (by fourth century A.D. in China).

The so-called gunpowder mill had been known in China since c. A.D. 300 and presumably spread west with gunpowder itself about the fourteenth century. Playing with the helicopter (or 'Chinese') top in 1796 led Cayley to his important studies which founded modern aerodynamics.

During the course of his address, Dr. Needham produced illustrations and other evidence showing the so-called 'Cardan' suspension in China, c. A.D. 180 , and the 'south-pointing carriage' of about the same time, based on a workable system of gear-wheels involving a principle still used-it might be regarded as the first of all cybernetic machines. European harness was, in ancient and early medieval times, very inefficient, as a load greater than half a ton tended to suffocate the horse. The Chinese horseload was $1_{2}^{1}$ tons ; the breast strap had been developed about the fourth and certainly by the third century B.C. and had spread to Europe, perhaps about A.D. 500. The collar harness developed by $c .700$ in China did not spread to Europe until c. 1200. Conversion of rotary to longitudinal motion was achieved in China long before the nineteenth century, indeed at least by A. .1313 . One idea which had passed from Europe via Islam to China was the pot-chain pump (Saqiya). The Vitruvian vertical waterwheel had also passed from Europe to China.

Ideas developed apparently independently in both Europe and China included the waterwheel (see above), the hodometer and the paddlewheel boat. An illustration of c. A.D. 170 of a hodometer showed five passengers in a carriage on the top of which automatic figures beat out the distances on a drum 
every $l i$. With regard to the paddlewheel boat, we must now assume that the anonymous Byzantine "De Rebus Bellicis" of c. A.D. 370 was genuine but uninfluential. The idea also developed in China about the sixth century.

Water-raising machinery such as the swape (shaduf) with its origin in the Fertile Crescent had reached China by A.D. 170 and probably much earlier. Water-power developed in the West and China at just about the same time. The Pontus water-mill of 65 B.c. (Strabo) is followed within a century by water-power applied in China (A.D. 31) to blowing blasts of air for iron furnaces and forges with the use of complex machinery, so that considerable previous development has to be postulated.

In those cases where China borrowed from the West, the sources are sometimes explicit. Thus Ling Lun, the legendary minister of the Yellow Emperor, is said to have obtained the harmonic progression by travel to the West just as Pythagoras is said to have travelled in Asia. The origin of both Greek and Chinese acoustics must be Babylonian. Likewise the seventh century horizontal windmills of the windy region of Seistan (East Persia) were specifically suggested as models for China by Yehlu Chhu-Tshai in the Mongol period. Some Central Asian prayer wheels used wind power so cleverly as to resemble cupanemometers.

Really now ideas which reached China through the Jesuits in the seventeenth and eighteenth centuries were few. The Chinese accepted from them the screw, the crankshaft, the cylinder-pump proper and cable ploughing. Gearing, cranes, the crank, the continuous chain excavator, etc., were unnecessary, as the Chinese already had them in use. The Chinese rejected some devices, such as the Vitruvian drumtreadmill (their pedals made it unnecessary), the Archimedean screw (though this was used for minedrainage in Japan), the vertical windmill and the flume-swape.

In the discussion which followed, several speakers expressed the hope that the illustrations and Dr. Needham's discoveries would soon be available in print.

\section{OBITUARIES}

\section{Dr. Bernard Lyot}

THE world of science, and French astronomy in particular, has suffered a severe loss in the sudden death, at the comparatively early age of fifty-four, of Dr. Bernard Lyot, one of the most brilliant observational astronomers of this century.

Lyot's early work in the 1920's consisted of measurement of polarization in the light of the moon and planets, and started characteristically. enough with the construction of a new sensitive polarimeter. With this he also examined a considerable number of terrestrial substances, and showed that the moon's surface behaves as though covered with a layer of volcanic ash or dust. He discovered a fairly close resemblance between the polarization from Mercury, Mars and the moon, he found that Mercury could have at most a very tenuous atmosphere, showed that polarization from Mars was sometimes affected by haze or dust, and discovered irregularities of polarization from the Martian south polar cap, which he attributed to the frequent formation of clouds.
His examination of the planet Venus, however, revealed a quite distinct behaviour, apparently due to the reflexion of sunlight from a cloud layer composed of droplets of refractive index near that of water, with diameters about $2 \mu$. Lyot also studied the polarization of light from Jupiter and Saturn, including Saturn's rings, finding a number of small effects still not fully explained.

In 1931 Lyot announced to an astonished and somewhat incredulous astronomical world that he had successfully observed the solar corona in full daylight. This feat had been attempted often enough in earlier years, sometimes by the most eminent observers, but had by then become to be generally regarded as impossible. Lyot had nevertheless succeeded, by inventing a new form of telescope in which all sources of scattered or false light were rigorously suppressed, and by using it in the best weather on the Pic du Midi (altitude $2,870 \mathrm{~m}$.), up which he himself carried much of the equipment, on skis. 'I'wo years later he had made a polarizing filter of the type now known by his name, permitting (in contrast with the spectroheliograph) simultaneous photography over a field as big as the solar disk, in a spectrum band of the order of $1 \mathrm{~A}$. wide. With this and with spectrographic equipment he worked on the Pic du Midi during the 1930's, following a very active programme of observation of the corona and the prominences, adding greatly to our knowledge of both. He measured the changes of surface brightness in the corona from day to day, particularly in the green and red emission lines, explored its spectrum thoroughly, adding five new lines and classifying the whole emission spectrum (its origin then still unknown) into groups of lines with common characteristics. He showed that the lines are wide and that their width increases with wave-length, and he demonstrated that the corona rotates at least approximately with the rest of the sun. He also studied prominence spectra, measuring the polarization in the continuous spectrum and in the lines $H \alpha$ and $D_{3}$, and produced some of the first cinematograph films showing prominence movements, films which are still unsurpassed in their fineness of definition.

Lyot's work relied on the production of flawless optical surfaces; he therefore invented new and sensitive methods of examining by phase contrast minute irregularities in the polish of a lens surface, and of discovering small inhomogeneities in large glass disks. Among his later achievements, he designed a large $f / 1$ spectrograph for studying the light of the night sky; he attempted to detect a lunar atmosphere and showed that there is none with a density greater than $10^{-8}$ of the earth's atmosphere; he devised and used a simple but sensitive polarimeter for examining minor planets ; his photographs of Miars and other planets are among the best yet obtained.' Within the past two years he had published a method by which he had successfully observed the corona at sea-level. His last work consisted of spectroscopic observations of the corona at the total solar eclipse of February 25 of this year, and it was while travelling in Egypt shortly after this that a recurrence of heart trouble led to his death.

A man of charming modesty, Lyot had during the past twenty years built up a well-deserved international reputation for the originality and elegance of his methods, and for his powers as an observer. Looking back over his career, one is impressed not 